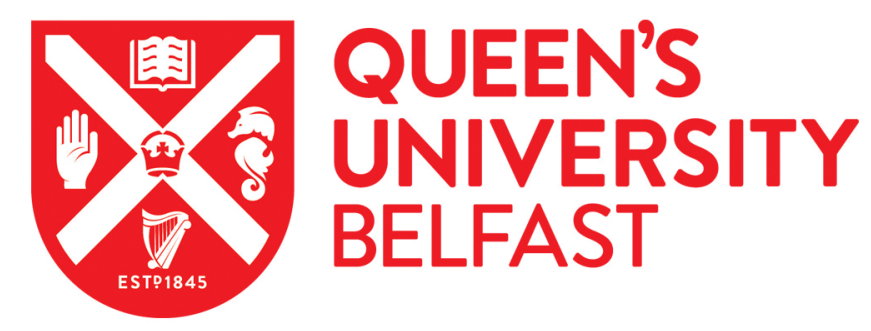

\title{
Knowledge of the Weather in the Middle Ages: Libellus de disposicione totius anni futuri
}

Cesario, M. (Ed.) (2018). Knowledge of the Weather in the Middle Ages: Libellus de disposicione totius anni futuri. In Aspects of knowledge: Preserving and reinventing traditions of learning in the Middle Ages Manchester University Press.

Published in:

Aspects of knowledge: Preserving and reinventing traditions of learning in the Middle Ages

Document Version:

Peer reviewed version

Queen's University Belfast - Research Portal:

Link to publication record in Queen's University Belfast Research Portal

Publisher rights

(c) Manchester University Press.

This work is made available online in accordance with the publisher's policies. Please refer to any applicable terms of use of the publisher.

\section{General rights}

Copyright for the publications made accessible via the Queen's University Belfast Research Portal is retained by the author(s) and / or other copyright owners and it is a condition of accessing these publications that users recognise and abide by the legal requirements associated with these rights.

Take down policy

The Research Portal is Queen's institutional repository that provides access to Queen's research output. Every effort has been made to ensure that content in the Research Portal does not infringe any person's rights, or applicable UK laws. If you discover content in the Research Portal that you believe breaches copyright or violates any law, please contact openaccess@qub.ac.uk. 


\section{Knowledge of the Weather in the Middle Ages: Libellus de disposicione totius anni futuri $^{1}$}

\section{Marilina Cesario}

In the Middle Ages extreme weather events, such as heavy rain and snowfalls, showers of hail, heat waves, droughts, floods, and unseasonably warm or cold temperatures, would have had catastrophic effects on many areas of society, chiefly on farming, seafaring, health and commerce. Environmental knowledge and weather forecasting based on the observation of the behaviour of the current weather and season, and of meteorological phenomena, was of paramount importance to those societies whose economic fortunes were heavily dependent on agriculture and livestock farming. Weather forecasts, which required knowledge of the related topics of astronomy and the reckoning of time, would therefore advise farmers on the most propitious times to plant and on those when it would not be advisable to begin their operations, especially when rains and winds were threatening, which could bring their toils to naught.

References to meteorological prediction and information about the seasons frequently appear in calendars, and more detailed descriptions of disastrous weather events and their harmful impact upon growing crops, houses, animals and men consistently feature in medieval annals and chronicles. A typical example is the following entry in The Annals of Fulda where we learn that in 872

Omne tempus aestivum grandinibus variisque tempestatibus pernoxium extitit; nam grando plurima loca frugibus devastavit; horrida etiam tonitrua et fulmina 
pene cotidie mortalibus interitum minabantur, quorum ictibus praevalidis homines et iumenta in diversis locis exanimata et in einerem redacta narrantur.

(The whole summer was ruined by hailstorms and other kinds of tempest. The hail destroyed the crops in many places, and terrifying thunder and lightning threatened mortals almost daily with death: it is said that immense bolts killed men and draught animals in various places and reduced them to ashes). ${ }^{2}$

Some meteorological phenomena, chiefly winds, thunder and lightning were often associated with fears of divine action and therefore endowed with prophetic significance. The chronicler's effort to confer a portentous function to anomalous weather occurrences and connect them to terrestrial happenings is evinced in the annal for the year 857 (Annals of Fulda) where the terribilem valde tempestatem (exceedingly terrible storm) and fulmen inorme ignei draconis (powerful lightningbolt like a fiery dragon), which killed three holy men and badly injured another six at Cologne and Trier, are described as prodigia 'marvels', 'portents'. ${ }^{3}$ Timothy Reuter argues that those strange prodigia were taken as signs foretelling the depositions of Archbishops Gunther and Theotgaud, which would follow in the year $863 .{ }^{4}$ The chroniclers' effort to interpret the weather and their readiness to bring a particular political or historical event into suggestive relation with the appearance of a sign in the sky, may have been encouraged by the proliferation of prognostic texts, particularly from the eleventh century onwards, based on the observation of meteorological phenomena. As Trevor Dean observes, 'chronicles were thus in part looking to the future: they shared in a wider desire for foreknowledge'. 5

Meteorological prognostics were more than a guide to the earth's changing 
seasons; they were firmly connected to the economy of a country, and could be consulted as a guide to the nation's or an individual's prospects. ${ }^{6}$ The most popular of all prognosticatory texts, which survives in hundreds of copies in several languages, transmitted continuously between the eighth and the sixteenth centuries, and known as the Revelatio Esdrae, offers forecasts of the weather for the year to come and then extends its predictions to the field of human affairs. ${ }^{7}$ The Revelatio appears prominently in computus manuscripts alongside medical and scientific works and in conjunction with other meteorological texts, which may include prognostication by the wind and sun during the twelve nights/days of Christmas, thunder prognostication according to the months of the year, the days of the week and the cardinal points.

\section{A Book of the Weather: A Case Study of MS Landesbibliothek und}

\section{Murdardsche Bibliothek der Stadt Kassel, med. $4^{0} 8$ (s. xv)}

It may be challenging for readers today to appreciate fully medieval approaches to weather forecasting, so accustomed are we to thinking of weather predictions in relation to Weather Apps, computer-based models, weather stations and satellites, and meteorological radars, which offer information on local precipitation and intensity. As Paul E. Dutton posits,

\footnotetext{
'Weather' is properly historical and stubbornly subjective, since it involves humans in time thinking about it and how it affects their lives. By reversing the process, we can, by studying their 'weather', also study them, their preoccupations, economic and social concerns, and cosmological and religious ideas. To study the weather is to study the human. ${ }^{8}$
} 
So, what can be learned from medieval weather reports? Can a study of the weather offer a glimpse into monastic psychology, how medieval people looked up to those types of texts, their relationship with time, the heavens and the body and their preoccupations with birth and health? Moreover, do we get any information about the political, social and economic conditions of the country in which a given text may have been copied? And finally how were those texts read and used? The fifteenthcentury medical manuscript Kassel, Landesbibliothek und Murdardsche Bibliothek der Stadt Kassel, med. $4^{0} 8$ [henceforth $\mathbf{K}$ ] from Germany is used here as a case study in an attempt to answer those questions.

$\mathbf{K}$ includes an intriguing collection of seven short meteorological treatises copied by the same hand as part of an independent section, which, I believe, exemplifies the sum of all the knowledge about weather forecasting which would have been available to medieval 'meteorologists'. The first folios of the manuscript, which are heavily annotated, contain a medico-botanical synonym list (synonyma apothecariorum, fols $1 \mathrm{r}-32 \mathrm{r}),{ }^{9}$ followed by a medical poem Carmen de urinibus by the French physician Aegidius Corboliensis (fols 32v-37v), medical recipes, and various tracts by Hippocrates and Galen (fols 30r-94r). Easter tables ('tabula Dionysii', 'tabula Friugonis' and 'tabula indicationis') follow on fols 94v-106r, and a text on 'omnis materia medicinalis' takes over on fol. 106r. The meteorological section begins on fol. 107r, where at the top of the page the scribe added the title Libellus de disposicione totius anni futuri (A little book on the disposition of the entire year to come) which comprises the following prognostications: Revelatio Esdrae or weather predictions for the year to come (I); 'On the disposition of the year according to the sound of the thunder during the Octave of the Nativity' (II); 'On the 
disposition of the year according to the winds' (III); 'On the disposition of the year according to fair weather during the twelve days' (IV); 'On the disposition of the year according to the months during which thunder is heard' $(\mathbf{V})$; a rare text where salt is used to predict rain (VI); and 'How they predict the nature of the year from the night of the Circumcision of Christ' (VII). The manuscript ends with more recepta varia (fols $107 \mathrm{v}-108 \mathrm{r}$ ) added by a different hand. ${ }^{10}$

\section{Edition and Translation}

By way of orientation it may be useful at this stage to introduce the meteorological prognostics in $\mathbf{K}$, which to my knowledge, are published here for the first time:

Libellus de disposicione totius anni futuri ${ }^{11}$

[Fol. 107r] Hec ${ }^{12}$ presagia dedit dominus esdre prophete. Si dies circumcisionis domini finerit die dominico. hyemps erit bona. ver humidum et calidum ventosum et sudus. estas erit sicca ventosa. annona bona. vindemie vbertas. oues et boues crescent. mel habundabit. pax erit. senes morientur. fructus ortorum peribunt pungne ${ }^{13}$ erunt in oriente. noua aliqua audiantur a regibus et principibus.

$\mathrm{Si}$ in secunda feria finerit hyemps mixta erit et quodammodo vmbrosa et interdum gelu forte. ver bonum. estas temperata ventosa. diluuia multa erunt. messes sicca. vindemie peribunt. turpes homines morientur. ${ }^{14}$ bella multa erunt. mutaciones principum. reges peribunt. apes peribunt. frumentum medio modo.

Si tertia feria. hyemps magna et bona. et in parte ventosa. ver ventosum et humidum. estas ventosa et sicca. frumenti copia. mulieres grauide morientur. autumpnus siccus. repentina mors regnabit. nalu/es peribunt. mellis habundancia. incendia multa. magna pestilencia. fructus ortorum peribunt. oleum habundabit. 
Si feria quarta hyemps mala et calida. ver humidum et ventosum. estas mixta. annone vilitas erit. frumentum bonum. vindemia bona. pomorum vilitas. olei habundancia. virorum iuuenum et mulierum interitus. bella et multe contenciones mercatores habundabunt. ventris precordiorum dissoluciones per multa loca fames. et aliquid noui a remotis audietur.

Si feria quinta hyemps erit temperata. ver ventosum. estas bona. vindemie habundancia. autumpnus bonus. reges et principes morientur et pax erit. frumenti vilitas. lini caritas. mel parum. porci et oues morientur. pluuie multe. flumina tument. oleum habundabit. annona medio modo.

Si sexta feria hyemps mixta. ver bonum sed ventosum. estas mixta annona bona. frumenti vilitas. vindemia bona. apes morientur. dolor oculorum. paruuli morientur. terremotus per loca arenosa. peregrinacio regibus et principibus. oleum habundabit et clamor magnus erit super principes.

Si sabbato. hyemps dura et ventosa. annona cara. frumenti erit angustia. autumpnus siccus. vindemia bona. paruulorum interitus. lini habundancia. triticum dominabitur. languores vexant senes vsque ad mortem. multa erunt incendia domorum. magni domini pacificabuntur et pax erit. terremotus in quibusdam locis. prophete multi egredientur futuri.

De disposicione anni secundum tonitrua per octaua Christi. Tonitrua in die nativitatis Christi significat magnam tempestatem maris et iram celestem. Secunda die significat natiuitatem regis vel mortem eius. Tercia die significat bellum magnum in gentibus. Quarta die significat mortalitatem populi dei. Quinta die iram celestem vel diem nouissimi apropinquare. Sexta die obitum alicuius sancti hominis. Septima die natiuitatem vel electionem magni regis significat. 
De disposicione anni secundum ventos. Si venti magni erunt ipsa nocte natiuitatis Christi reges et principes et tributarij peribunt. Si secunda nocte viri et ingrati ${ }^{15}$ deficient. Si tertia nocte panis habundabit. Si quarta nocte artifices peribunt. Si quinta nocte artifices erunt in scandalo. Si sexta nocte principes ibunt ad bellum et non peribunt. Si septima [fol. 107v] nocte erunt incendia. Si octaua nocte senes morientur. Si nona nocte omnia ligna confringentur. ${ }^{16} \mathrm{Si}$ decima nocte pecora peribunt. Si Ivn/decima nocte magni domini in bellis peribunt. Si duodecima nocte deus exorandus est perpetuo.

De disposicione anni secundum serenitatem duodecim dierum. Si dies natiuitatis Christi serena fuerit letabuntur omnes fideles Christi. ${ }^{17} \mathrm{Si}$ secunda dies serena fuerit revelabuntur aurum et argentum. Si tertia dies bellum erit in gentibus.

Si quarta dies vinum habundabit et vituli equorum prosperabuntur. Si quinta frumenti copia erit. Si sexta glandes habundabunt. Si septima copia lactis vacce ouis et boues habundabunt. Si octaua copia piscium erit. Si nona oues et boues prosperabuntur. Si decima dies serena fuerit argentum habundabit. Si vndecima mortalitas hominum erit. Si duodecima infirmitates immedicabiles erunt.

Alia prophecia

De disposicione anni secundum menses per tonitrua. Si tonitrua in ianuario sonuerint. validos ventos et habundanciam et bellum illo anno significat. Si in februario multorum hominum et maxime diuitum morbum et interitum. Si in martio ventos validos et habundanciam frugum et lites in populo significat. Si in aprili annum iocundum et fructiferum et mortem iniquorum hominum significat. Si in maio frugum inopiam et famem et varias infirmitates significat. Si in iunio habundanciam frugum et varias infirmitates significat. Si in iulio. bonam annonam et interitus fetus et pecorum significat. Si in augusto. prospera rei publice egrotare multos et precipue 
sutores significat. Si in septembri habundanciam frugum et interitus hominum et maxime potentum significat. Si in octobri anona ${ }^{18}$ bona sed alterius frumenti erit trinorum. et ventum validum et arborum fructus copiam significat. Si in nouembri sterilitatem frugum et annum tempestuosum significat. Si in decembri habundanciam annone et pacem in populo et concordiam in omnibus significat.

Si vis scire in quo mense magis pluat per circulum anni tunc attende primam noctem mensis ianuarij accipe discum latum vel trabesetum et in eius concauita pone duodecim cumulos salis nominando omnis menses per ordinem incipiendo a ianuario vsque ad ultimum mensem scilicet decembrem hoc secundum discum vel trabesetum in quo ponense salis cumulos in celario vel in loco secreto siccare sub terra per noctem loca et de mane considera de quo cumulo magis exeat de aqua in illo mense magis pluet et de quo cumulo minus exiet de aqua et in illo mense minus pluet secundum phisicos.

Qui de nocte diei circumcisionis domini naturam anni predicunt. dicunt quidem. si serena nox fuerit sine vento et pluuia. bonus annus in omnibus rebus erit. Si ab oriente ventus flauerit pecora et pecudes peribunt. Si ab occidente reges et principes morituros significat. Si ab meridie etiam infirmitates et mortes hominum significat. Si ab aquilone annum infructuosum demonstrat.

(A little book on the disposition of the entire year to come.

(I) Here [are] the prophecies that the Lord gave to Esdras the prophet. If the feast day of the Circumcision of Christ falls on a Sunday, there will be a good winter, a wet, hot, windy and bright spring, there will be a dry and windy summer, good year's produce, copious grape harvest, sheep and cows will thrive, honey will abound, there 
will be peace, old men will die, the fruits from the gardens will perish, there will be fighting in the east, some novelties will be heard of kings and princes.

If [the feast day of the Circumcision of Christ] falls on a Monday, there will be a mixed winter, and somewhat shady, and hard frost, a good spring, a temperate and windy summer, there will be many floods, crops will be dry, grape harvest will perish, ugly ${ }^{19}$ men will die, there will be many wars, changes of princes, kings will die, bees will die, corn in moderate measure.

If [the feast day of the Circumcision of Christ falls on] a Tuesday, [there will be] a great and good and partly windy winter, a windy and wet spring, a windy and dry summer, plenty of corn, pregnant women will die, [there will be] a dry autumn, sudden death will dominate, ships will be destroyed, [there will be] abundance of honey, many fires, many plagues, the fruits from the gardens will perish, [and] oil will abound.

If [the feast day of the Circumcision of Christ falls on] a Wednesday, [there will be] a bad and warm winter, a wet and windy spring, a mixed summer, cheap produce, there will be good corn, good grape harvest, cheap fruits from the trees, abundance of oil, men, young people and women will die, [there will be] wars and many disputes, merchants will prosper, weakness of the stomach and of the intestines, [there will be] famine in many places, and some news will be heard from afar. If [the feast day of the Circumcision of Christ falls on] a Thursday, there will be a temperate winter, a windy spring, a good summer, abundance of grape harvest, a good autumn, kings and princes will die and there will be peace, crops [will be] cheap, flax [will be] dear, [there will be] little honey, pigs and sheep will die, [there will be] heavy rainfall, rivers will swell up, oil will abound, [and] the year's produce in moderate measure. 
If [the feast day of the Circumcision of Christ falls on] a Friday, [there will be] a mixed winter, a good but also windy spring, a mixed summer, good year's produce, cheap crops, good grape harvest, bees will die, [there will be] eye-pain, children will die, [there will be] an earthquake in sandy places, travel of kings and princes, oil will abound, and there will be much clamor concerning princes.

[If the feast day of the Circumcision of Christ falls on] a Saturday, [there will be] a harsh and windy winter, dear grain, dearth of natural produce, [there will be] a dry autumn, good grape harvest, death of children, abundance of flax, wheat will dominate, feebleness will trouble old men all the way to death, many houses-fires, great lords will make peace and there will be peace, [there will be] an earthquake in some places, [and] many future prophets will come forth.

(II) On the disposition of the year according to the sound of thunder during the Octave of the Nativity. [If] the sound of thunder is heard on Christmas Day, it portends a great sea storm and wrath from heaven. On the second day, it portends the birth of a king or his death. On the third day, it portends great war amongst people. On the fourth day, it portends death of God's people. On the fifth day, [it portends] wrath from heaven or the last day will be near. On the sixth day, [it portends] the death of some holy men. On the seventh day, it portends death or election of a great king.

(III) On the disposition of the year according to the winds. If there are great winds that same night of Christ's birth, kings, princes and tributaries will die. On the second, night men and the unpleasant will diminish in number. On the third night, bread will abound. On the fourth night, professionals will die. On the fifth night, craftsmen will fall into temptation. On the sixth night, princes will go to battle and they will not die. On the seventh night, there will be fires. On the eighth night, old men will die. On the 
ninth night, timber will disintegrate. ${ }^{20}$ On the tenth night, sheep will die. On the eleventh night, great lords will die in battle. On the twelfth night, may the Lord be praised eternally.

(IV) On the disposition of the year according to fair weather during the twelve days. If there is fair weather on the day of Christ's birth, all Christ's faithful will rejoice. If the weather is fair on the second day, gold and silver will be uncovered. On the third day, there will be war amongst the people. On the fourth day, wine will abound and horses' foals will prosper. On the fifth [day], there will be abundance of grain. On the sixth [day], acorns will abound. On the seventh [day], [there will be] abundance of cows' [and] sheep's milk, and cows will increase. On the eighth [day], there will be [abundance of] fish. On the ninth [day], sheep and cows will thrive. If the weather is fair on the tenth day, silver will abound. On the eleventh [day], [there will be] death of men. On the twelfth [day], [there will be] incurable diseases.

(V) Another prediction. On the disposition of the year according to the months during which thunder is heard. If thunder is heard in January, it portends a strong wind and abundance and war in that year. If [thunder is heard] in February, it portends disease and destruction of a multitude of men and especially rich [men]. If [thunder is heard] in March, it portends a strong wind and abundance of fruits of the earth and disputes amongst the people. If [thunder is heard] in April, it portends a happy and fruitful year and death of unjust men. If [thunder is heard] in May, it portends scarcity of fruits, and famine, and various diseases. If [thunder is heard] in June, it portends abundance of fruits and various diseases. If [thunder is heard] in July, [it portents] a good year's produce, and destruction of offspring and cattle. If [thunder is heard] in August, it portends prosperity of the state and many will be sick, and especially shoemakers. If [thunder is heard] in September, it portends abundance of the fruits from the earth and 
death of men, and especially powerful [men]. If [thunder is heard] in October, it portends good year's produce, but of other grain there will be triple [harvest], and a strong wind and abundance of fruits from the trees. If [thunder is heard] in November, it portends unfruitfulness and a tempestuous year. If [thunder is heard] in December, it portends abundance of crops and peace amongst the people and union amongst everyone.

(VI) If you wish to know in which month it will rain the most during the course of the year, then, wait for the first night of the month of January, take a broad dish or else a beam of wood and put twelve heaps of salt in hollows in it, after naming all twelve months in succession, beginning with January up to the last month, [that is] of course December. Here [place] the propitious dish or wooden beam in which you put the heaps of salt in a cellar or in a secret place underground in which to drain out through the night, and in the morning examine from which heap comes out most of the water, in that month it will rain the most, and from which heap less water comes out, according to natural philosophers, in that month it will rain less.

(VII) How they predict the nature of the year from the night of the Circumcision of Christ, in fact they say [that] if the night [of the Circumcision of Christ] is clear with neither wind nor rain, it will be a good year for everything. If the wind blows from the east, sheep and cattle will perish. If [the wind blows] from the west, it indicates that kings and princes will die. If [the wind blows] from the south, it indicates diseases and also death of men. If [the wind blows] from the north, it indicates an unprofitable year). 


\section{An Anthology of Weather-Lore}

All items on fol. 107rv, with the exception of the salt calendar (VI), to which I shall return later, fit into the typical if ... then (protasis ... apodosis) structure which defines most prognostic texts in which natural phenomena are observed as indications of future events. The title at the top of the folio, Libellus de disposicione totius anni futuri, gives readers a clear indication that the meteorological treatises which make up the collection offer predictions for the year to come, a far cry from our too familiar day-to-day or five-day weather forecasts. ${ }^{21}$ Furthermore, they display broadly similar features and are placed within a temporal framework (dies circumcisionis domini $[\mathbf{I}$, II and VI]; xii. noctibus in natali domini [III, IV]; menses $[\mathbf{V}, \mathbf{V I}])$, and are easy to read and comprehend, a feature assisted by the use of punctuation which separates the predictions (punctus), and repetitive, simple language. The main questions they attempt to answer are also essentially the same; e.g., what will the weather be like? Who will die this year? Will livestock thrive?

The kalendologion ${ }^{22}$ (I) contains a typical incipit which ascribes the text to Esdras the prophet (Hec presagia dedit dominus esdre phophete) ${ }^{23}$ and gives longterm predictions from the day of the week on which the dies circumcisionis domini falls. It begins the day with a section including acts of nature, such as pluuia and siccitas for hyem, ver and estas, and what may be related to the weather, including naues peribunt, terremotus and incendia. Given the damage unseasonable weather could cause to agriculture, it is unsurprising that most predictions are concerned with food production or lack of it (fructus ortorum 'fruits from the garden' messes 'crops', annone 'produce', triticum 'wheat', frumentum 'corn', lini 'flax', pomi 'fruit trees', oleum 'oil', fames 'famine', glandes 'acorn' [IV]) and livestock farming (oues, boues, apes, porci, pecude 'cattle' [VII] and vituli equorum 'horses' foals' in [IV]). Not only 
do changes in weather lead to environmental disturbances, but are also intimately interconnected to diseases, the ones mentioned being magna pestilencia 'great plagues', ventris praecordiorum dissoluciones 'weakness of the stomach and of the intestines' and dolor oculorum 'eye-pain' (I).$^{24}$ The second section of the revelatio is typically concerned with more terrestrial and mundane activities, including deaths and political and military matters: bella 'wars', pax 'peace' amongst the people, mutaciones principum 'changes of regime', death of kings and princes. The other categories affected may comprise viri, mulieres, mulieres grauide, iuиenes, paruuli, senes, turpes homini, mercatores, prophete.

Notwithstanding a couple of uncommon predictions, one which displays an interest in eastern affairs pugne erunt in oriente (there will be battles in the east) and an allusion to prophete multi egredientur futuri (many future prophets will come forth), the latter closing the prognostication, most prophecies in I do conform to those found in other texts, although no two surviving versions of a kalendologion are identical. It can therefore be argued that scribes developed a blueprint for these prognostications, which allowed their standard shape to be fixed through the centuries, and as a result most prophecies are universal and could indeed apply to any country and historical period. However, one cannot deny that meteorological prognostics, which were customarily written, circulated and received in connection with each other, were subject to individual variations and embellishments. At times particular scribes adapted their sources for the readers among whom a text was to circulate, and attention to apparently insignificant differences in the main text may throw light on what may have been of appeal to a particular country. A case in point may be afforded by the prophecy for the month of August in $\mathbf{K}$ (thunder prognostication $[\mathbf{V}]$ ) which foretells prospera rei publice egrotare multos et precipue 
sutores significat 'prosperity of the state and many will be sick, and especially shoemakers'. The reference to sutores, which, as far as I am aware, is unique to the version in $\mathbf{K}$, might point to the monopoly position of shoemakers in medieval Germany, who after the Great Plague of 1349 controlled most of the foreign shoemaking trade. ${ }^{25}$ The interpolation of sutores in a fifteenth-century copy produced in Germany might be a deliberate attempt on the scribe's part to make the text relevant to its readers. There is in fact no mention of 'shoemakers' in the earlier versions of the prognostication in the Old English London, BL, MS Cotton Vespasian D. xiv, fol. 103v (s. xii) and in the Latin London, BL, MS Egerton 2852, fol. 107v (s. xiv) of which $\mathbf{V}$ is nearly an exact copy. ${ }^{26}$

Certain other additions may point to the country in which a given text may have been produced, as might be the case in the Old English prognostication by the sun in Hatton 115, fols $149 \mathrm{v}-150 \mathrm{r}$, where the English are the main addressees of the prophecy: Gyf by afteran daeg sunne scynep. ponne byð on angel cynne gold eaðbegeate (if the sun shines on the second day, then gold will be easy to obtain among the English). ${ }^{27}$ Furthermore, England is mentioned in the fifteenth-century prognostication by the wind in London, BL, MS Egerton 1995, fol. 60v: In illo anno incendium domorum igne quasi per universum Anglie esse significat (In that year it signifies that there will be burning of the houses because of fire nearly throughout the whole of England). It is safe to assume that these predictions were intended for an English audience interested in the destiny and wealth of their own country.

In II, III, IV, V and VII the climatic phenomena of thunder, wind and sun are viewed as prophetic signs which give foreknowledge of future events. II and $\mathbf{V}$ are examples of brontologies, a genre, that as David Juste and Hilbert Chiu remark, 'belongs to a very old tradition, whose earliest extant examples can be traced back to 
cuneiform tablets of the Neo-Assyrian period (ca. 1000-612 B.C.)'. ${ }^{28}$ The unfavourable occurrences anticipated in II, which are placed within an eight-day period, per octaua Christi, starting on die nativitatis until the first of January, carry obvious religious implications. Iram celestem 'wrath from heaven', which appears twice, once in connection with tempestatem maris (on die nativitatis Christi), and another in relation to the approaching of diem nouissimi (on secunda die), no doubt stems from Biblical accounts where the voice of God, usually signifying judgement, is likened to thunder: et audivi vocem de caelo tamquam vocem aquarum multarum et tamquam vocem tonitrui magni 'and I heard a voice from heaven, as the noise of many waters and as the voice of great thunder' (Rev 14:2). Other religious references in II include mortalitatem populi dei (death of God's people) on tercia die and obitum alicuuius sancti hominis (death of some holy men) on quinta die. No evident religious symbolism is attached to the other brontology in the collection, this time arranged according to the months of the year on which thunder is heard, tonitrua sonuerint $(\mathbf{V})$, which the scribe labels alia prophecia (another prophecy). The majority of its predictions, in a similar vein as those contained in $\mathbf{I}$, exhibit diverse agricultural and human concerns: validos ventos, annum tempestuosum or iocundum et fructiferum, sterilitatem or abundancia frugrum, famem, bellum, lites or pacem populo, mortem, infirmitatem and concordiam in omnibus.

The wind is the main predictive agent in III, a fairly widespread prognostication which bases its predictions on the blowing of the wind during the twelve nights of Christmas. ${ }^{29}$ The earliest known Latin exemplar for this prognostication appears in the ninth-century computistical Paris, Bibliothèque Nationale, n.a.l., MS 1616, fol. 12v, from Fleury. ${ }^{30}$ The version in K closely agrees with a late eleventh-century copy in Bibliothèque de L'Université de Liège, MS 77, 
fol. $69 \mathrm{v}$, probably produced in Liège. In line with the negative symbolism of the wind, the two versions mainly announce misfortunes, including death of people and cattle (reges, principes, tributarij, viri ingrati, artifices, senes, magni domini and pecora), fires (incendia), battles (bella) and shortage of timber (ligna confringentur). However, positive prophecies do occur on the third night where abundance of bread is prophesied, and on the sixth where princes will not die in battle. III concludes the prognostication with an encouraging invocation to the Lord: deus exorandus est perpetuo (may the Lord be praised eternally). ${ }^{31} \mathrm{~A}$ more positive note, in accordance with the auspicious nature of the sun, is sounded in the prognostication secundum serenitatem duodecim dierum (IV), which follows the wind, and of which fewer versions have survived. To my knowledge, the earliest copies are attested in two eleventh-century manuscripts: Cambridge, CCC MS 391, p. 713, and Bibliothèque de L'Université de Liège, MS 77, fol. 69v ${ }^{32} \mathbf{I V}$, as most other continental analogues, mainly portends joy amongst Christ's faithful (fideles Christi), gold and silver (aurum et argentum), abundance of wine, grains, acorns, cows' and sheep's milk, fish, cows, sheep and horses' foals (vinum, frumenti, glandes, lactis vacce ouis et boues, piscis, oues, boues, vituli equorum). ${ }^{33}$ As was the case with the wind, unexpected prophecies, this time negative, make an appearance on the third, eleventh and twelfth days.

Whereas several directional brontologies have been identified as part of the $D e$ tonitruis, a set of texts based on thunder divination, ${ }^{34}$ VII, the final item of the meteorological section, is a little-known example of wind prognostication which purports to predict naturam anni 'the nature of the year' according to the four cardinal directions (ab oriente, occidente, meridie and aquilone) from the nocte dies circumcisionis domini. ${ }^{35}$ The prognosticon states that a clear sky on the night of the circumcision of Christ signifies a profitable year (bonus annus on omnibus rebus erit), 
but if the wind blows, no matter from what direction, it presages an unproductive year, and deaths of various kinds. A directional wind prognostication in Coptic has survived in a single leaf from a late ninth-century parchment codex (P. Mich inv. 590) where it is part of a kalendologion, referred to by Gerard M. Browne as a 'subliterary manual'. The text begins its predictions on 6 Tubi (the beginning of the year in the Coptic calendar) which may correspond to the dies circumcisionis domini in VII:

This is the sign of 6 (?) Tubi concerning the way in which we are taught what is profitable to us before it happens. If the east wind comes forth on that day, the water is good, and it will cover the entire earth, the cattle will live, the crops will blossom, the honey will diminish, and the last of the crops of the field will perish. ${ }^{36}$

For that specific day VII predicts that ab oriente ventus flauerit pecora et pecudes peribunt (if the wind blows from the east, sheep and cattle will perish). The Coptic text appears to be more elaborate; in fact, emphasis is placed not only on the cardinal directions, but also on the time of the day on which the wind is blowing: 'If a south wind comes forth on the dawn of 9 Tubi, and the north wind comes forth at evening [... '). Furthermore, it attributes positive or negative prophecies to the direction from which the wind comes forth, whereas VII simply reinforces the analogical link between the negative value of the sign (protasis), that is the destructive force of the wind, and the threatening effect (apodosis) which is naturally expected. This seems to suggest that the logical cause-effect relationship between portent and prediction was not necessarily inferred from experiential knowledge, but rather as Leo Oppenheim proposed, with regard to divination practices in ancient Mesopotamia, 'sometimes subconscious associations [were] provoked by certain words whose specific 
connotations imparted to them a favourable or an unfavourable character, which in turn determined the general nature of the prediction' ${ }^{37}$ The suggested relationship between antecedent and consequent, which relies heavily upon universally accepted categories, would explain why the meteorological phenomena of wind and thunder were generally viewed as harbingers of ominous occurrences, and by contrast the sun was taken as the forerunner of something good. The same may be argued in relation to I where most predictions replicate the positive or negative value attributed to each day of the week. The idea of Sunday as a positive day, in which there is to be no fasting or kneeling, is mostly reproduced in the Revelatio, which for Sunday predicts good weather and abundance of crops and sheep, ${ }^{38}$ whereas the outlook for a year beginning on secunda feria is predominantly menacing. ${ }^{39}$ However, as noted previously, exceptions do occur, which can be ascribed to the long process of adding and editing that such texts underwent.

\section{Salt Calendar}

A puzzling text, in which salt is used to predict the rain for the year to come (VI), is embedded within more conventional weather prognostics. This unparalleled calendar, of which, to my knowledge, another classical or medieval witness has yet to be found, differs substantially from the other meteorological material and defies any precise and simple attempt of categorisation. It is in fact a blend of natural science, alchemical lore, experimentation and divination. Tony Hunt makes a useful distinction between prognostication and divination:

In divination there are prescribed actions which must be carried out before information to be observed is disclosed, whilst in prognostics what is 
necessary is observation and interpretation, without the necessity to execute any action in order to gain access to what is observed. ${ }^{40}$

VI is undoubtedly more akin to divination than prognostication; in order to know in quo mense magis pluat per circulum anni (which month it will rain the most during the year), it is imperative that on the first of January the following recommended actions must be carried out: take a broad dish or else a beam of wood and put twelve heaps of salt in hollows in it (accipe discum latum vel trabesetum et in eius concauita pone duodecim cumulos salis) and name all twelve months in succession from January to December. ${ }^{41}$ After that, the wooden dish ought to be placed in a cellar (celario) or in a secret place (loco secreto) underground throughout the night, and the next morning the salt will have dissolved into each hollow to varying degrees; the greater the amount of moisture the wetter the corresponding month will be in the coming year. By contrast, if the salt has kept its crystal shape, then that month will be dry.

The underlying chemical principle here is that due to its hygroscopic nature salt dissolves when exposed to the air or humid weather. Although to some degree all salts are hygroscopic, the one mentioned in the calendar is likely to be potash (potassium carbonate), which was known for several thousand years as it can be extracted with water from wood ash. ${ }^{42}$ If left in air, potassium carbonate will take more and more moisture and eventually can completely dissolve in this water forming a solution. This is what happens with that salt in a cellar in VI. The appearance of liquid in potash indicates that the relative humidity is above $43 \%$, not uncommon in northern Europe. ${ }^{43}$ At the same amount of water in air the relative humidity increases with decreasing temperature. That is why it is recommended to place the salt heaps in 
a celario (where it is usually cooler and more humid) to make sure that some liquid appears even during a hot and dry summer night. The amount of water absorbed will depend on the amount of salt in each heap; the more salt the more moisture will appear. As the recipe does not require to make heaps completely equal, the amount of water will be different and different amounts of moisture will appear, which suggests that perhaps no precise measurements were required. Given the lack at present of a known earlier analogue (if one does indeed exist), no definite statement can be made as to the origin of this text. Moving forward in time, VI might be the precursor of a seventeenth-century 'Onion Calendar', possibly originating in Hungary, where salt is positioned in twelve onion scales (corresponding to the twelve months, from January to December) to determine the rain and which, according to The Old Farmer's Almanac, is still very much in use today amongst farmers and gardeners. ${ }^{44}$ The two calendars only differ inasmuch as the trabs in the Kassel text has been replaced by the onion scales; this does not alter the experiment given that both onions and wood have hygroscopic qualities; they gain or loose moisture depending on the atmospheric conditions.

Notwithstanding the lack of an antecedent, one can confidently argue that, whoever devised this method of weather forecast, possibly someone with alchemical knowledge, must have been familiar with the hygroscopic properties of salts, in particular potash. Interestingly, VI points out that this method has been passed down by phisicos (natural philosophers), quite possibly Aristotle, who in Book IV, part 6 of the Meteorologica, the first study entirely devoted to meteorological occurrences, discusses at length the various kinds of salts. ${ }^{45}$ Moreover, an originally Arabic compilation on classifications of alums and salts attributed to al-Razi and considered one of the main contributions to modern chemistry, acquired great popularity in the 
late Middle Ages thanks to the twelfth-century Latin translation by Gerard of Cremona, entitled Liber de aluminibus et salibus. ${ }^{46}$ It is well known that the fourteenth and fifteenth centuries marked a significant development in approaches to alchemy in the West, thanks to Latin translations of Arabic and Greek texts made available within monastic and academic circles. ${ }^{47}$

It seems to me that the prognostic treatises in $\mathbf{K}$, mainly based on perception and arguably historical observations of empirical phenomena, were given more theoretical than practical usage, whereas VI, I would argue, relies instead upon knowledge acquired through experimentation. In his work On Experimental Science, Roger Bacon argues that 'reasoning' and 'experience' must be used in conjunction in order to acquire knowledge and understand nature: 'Reasoning guides us to a sound conclusion, but does not remove doubt from the mind until confirmed by experience'. ${ }^{48} \mathbf{V I}$, which combines a theoretical framework with experimentation and first-hand knowledge, undoubtedly contributes to the unifying and coherent purpose of the Libellus's main preoccupation with weather, time and the calendar.

\section{Conclusions}

This final section will briefly consider how the weather prognostica complement the medical and computistical material found in $\mathbf{K}$. Furthermore, it will question whether the meteorological treatises I-VII were viewed as academic texts, reserved for an erudite environment, which formed part of scientific and scholarly training, or else they were treated principally as popular works, for use by those readers, whether monks or laymen, who set store by almanacs. 
It should be noted, before addressing the issues above, that $\mathbf{K}$ is by no means the only medieval manuscript which devotes an entire section to meteorological material; it follows, to a certain degree, set patterns which are repeated in other compositions. It was relatively common practice, from the eleventh century onwards, for weather prognostics (revelatio, wind, sun and thunder) to be grouped in clusters, often in the form of booklets or separate quires, which could circulate independently of the rest of the manuscript and used for reference. ${ }^{49}$

One of the earliest surviving examples - with which some prognostics in $\mathbf{K}$ bear many similarities - from the end of the eleventh-century is MS 77 from Liège, where fols $62 \mathrm{v}-70 \mathrm{r}$ form an independent unit containing meteorological prognostications and extracts from Bede's De natura rerum and Isidore's work of the same title. ${ }^{50}$ The second prognostic text on thunder is the longest (fols $62 \mathrm{v}-68 \mathrm{r}$ ); it begins with the four cardinal points from which the thunder is heard, and then turns to the twelve months of the year, the seven days of the week, and the hours of the day. ${ }^{51}$ The thunder prognostication is followed by passages from Bede's De natura rerum, beginning with a sentence from chapter thirty-six on the signs of the tempest and by the Revelatio Esdrae and wind and sun prognostications, which generally circulated together, as is mirrored in the twelfth-century addition to Oxford, Bodleian, MS Hatton 115 (Canterbury or Worcester). Its fifth booklet (fols 148-155), consisting of two quires of four leaves each, contains a mix of prognostic texts including: dream lunarium, birth lunarium, individual birth prognostics by the week, Christmas Day, wind, sun, thunder (days of the week), dreambook, general lunarium. ${ }^{52} \mathrm{~A}$ similar body of material appears in the fifteenth-century astrological and medical compendium, London, BL, MS Sloane 282, which comprises a calendar of John Somer, tables of lunar and solar eclipses ${ }^{53}$ medical recipes, a copy of the Secretum secretorum ${ }^{54}$ and 
the following prognostications which appear on fols $86 \mathrm{r}-87 \mathrm{v}$ : revelatio (based on the calends of January), Christmas Day, wind and sun in the twelve nights/days of Christmas, thunder according to the months, and individual birth predictions. ${ }^{55}$ Interestingly, Sloane 282 includes two examples of the same class of prognostication: revelatio esdrae and Christmas Day, ${ }^{56}$ the only difference between them is the reckoning of the beginning of the year. ${ }^{57}$ The inclusion of different versions of the same prognostication within the same manuscript raises interesting questions about the utilitarian nature of such texts. If one indeed relied upon these texts for practical purposes, which version would be consulted? Would one be more reliable than the other? But if we were to take the two versions as symptomatic of the still prevailing confusion concerning the beginning of the year, whether it was taken to be the first of January or the $25^{\text {th }}$ of December, then having two versions in the same booklet would have been quite convenient.

There are clear signs of purpose in the assembling of the prognostics cluster in Liège MS 77 and K; all the items included are indeed concerned with the weather and the natural world. In Liège MS 77 this is further reinforced by the presence of abstracts from Bede's and Isidore's De natura rerum which frame the prognostications and provide the background knowledge of the physical phenomena of wind, thunder and sun. It could be argued that the Kassel scribe may have accessed the meteorological material in the form of a booklet or a separate quire where the texts had already been copied in that order. ${ }^{58}$ What contributes to the uniqueness of this collection is the presence of the salt calendar, which might have already been part of the scribe's exemplar. On the other hand, the inclusion of VI might be a reflection of the scribe's personal taste and their attempt to combine alchemical lore with meteorological knowledge. 
K encompasses what Linne R. Mooney refers to as 'scientific and utilitarian texts': medical material and three Easter tables interspersed between the herb-medical recipes and the weather prognostics. ${ }^{59}$ It is not far-fetched for prognosticatory and divinatory material to coexist in the same manuscript collection with compustical, and medical material. This is how Roy M. Liuzza explains this concurrence:

Like computus, they [prognostics] offer a glimpse of cosmic order beneath the chaos of time; like medicine, they reveal the regular pattern beneath the irregular course of illness. Like both, they are underwritten by a theory, though scarcely visible in surviving manuscripts, of the homology between the bodily humours, the seasons of the year, and the elements that make up the $\operatorname{cosmos}^{60}$

Given the prevalence of medical material in $\mathbf{K}$, one can hypothesise that the manuscript may have been commissioned and used by physicians and apothecaries for their own instruction and training.

To return to one of the questions addressed at the onset of this article: was the Libellus put to any practical use? Who would benefit from those meteorological texts? According to Tony Hunt, '[prognostic texts] represented in their day the organized knowledge or "science" of prognostication, at first best approached as booklearning. ${ }^{61}$ Hunt's view is supported by the fact that manuscripts containing prognostic texts rarely show concrete signs of use. ${ }^{62}$ The corrections, deletions, interpolations and scholia which fill the medical material in $\mathbf{K}$ support the assertion that such texts were constantly revised and consulted. On this point, Sàndor Chardonnens asks, in relation to Anglo-Saxon prognostics, 'why else would one 
revise, enhance or amend a text but to increase its legibility or facilitate its use? ${ }^{63}$ Noticeably, the energetic scribal intervention occurring in the medical texts reduces sensibly in the weather anthology in $\mathbf{K}$, where one encounters only occasional interlinear insertions. It appears that the Kassel scribes were more reluctant to make significant changes to prognosticatory and divinatory texts than to medical and computistical items. On the other hand, the additions of red ink to prognostics' headings, added by the same hand during the revision phase in order to assist speed of reference, may point, to borrow Chardonnens's terminology, to 'indirect signs of use'. ${ }^{64}$ Unfortunately, no records of the success or failure of specific prophecies have survived. By contrast, due to its instructional and experimental nature, VI, unlike the neighbouring prognostic texts, may have actually been designed for use. The instructions contained therein do resemble medical recipes where salt is used in a wide range of contexts, as a preservative for other ingredients, a mild antiseptic, and with herbs to draw out and stem. ${ }^{65}$

Whatever its intended use, the Libellus totius anni futuri aptly contributes to the manuscript's overarching interest in natural philosophy, which embraces inquiries and questions about the physical world through the knowledge and understanding of medical texts and herbal pharmacy, computistical learning and its applications (Easter Tables), natural science (weather prognostics), alchemical lore and experimentation (salt calendar).

\footnotetext{
${ }^{1}$ My gratitude goes to the Leverhulme Trust for enabling me to bring to completion this essay and other projects thanks to a Research Fellowship. I also wish to thank Dr Elizabeth Solopova and Professor Tony Hunt for their useful comments.
} 
${ }^{2}$ G. H. Pertz (ed.), Annales Fuldenses (Hannover: Impensis bibliopolii Hahniani, 1891), pp. 76-7. The translation is from Timothy Reuter (trans.), Annals of Fulda (Manchester: Manchester University Press: 1992) p. 68.

${ }^{3}$ Pertz, Annales Fundenses, p. 48.

${ }^{4}$ Reuter, Annals of Fulda, p. 40, n. 10.

${ }^{5}$ Trevor Dean, 'Natural encounters: climate, weather and the Italian Renaissance', European Review of History: Revue européenne d'histoire, 18 (2011), 545-61 (551). ${ }^{6}$ Tony Hunt defines meteorological prognostics as 'predictions predominantly about the weather from the weather (according to the wind, thunder, sunshine), largely based on Christmas Day and New Year's Day'. T. Hunt, Writing the Future: Prognostic Texts of Medieval England (Paris: Classiques Garnier, 2013), pp. 196-7. ${ }^{7}$ Anne Matter's valuable attempt to catalogue versions of the kalendae ianuariae and Christmas Day prognostications has been surpassed by Lorenzo DiTommaso, who offers a conspectus of 287 western manuscripts of the Revelatio Esdrae. The creation of a complete list of the surviving versions of the Revelatio remains a daunting task, since they are widely scattered amongst various astrological, medical and computistical collections, and new versions are constantly located. See L. DiTommaso, 'Pseudepigrapha Notes III: 4. Old Testament Pseudepigrapha in the Yale University Manuscript Collection', Journal for the Study of the Pseudepigrapha, 20 (2010), 3-80. Main studies of the revelatio include (these are by no means exhaustive): A. Boucherie, 'Dialectes anciens. Un almanach au xme siècle', Revue des Langues Romanes, 3 (1872), 133-45; G. Mercati, Note di letteratura biblica e cristiana antica. Studi e Testi, 5 (Rome: Tipografia Vaticana, 1901); M. Förster, 'Beiträge zur Mittelalterlichen Volkskunde', Archiv für das Studium der neuren Sprachen und Literaturen, 120 (1908), 296-301; P. Spunar, 'Ceské Zpracováni 
Esdrásova Proroctvi Ve Videnském Rukopisu ÖNB 3282', Sbornik Národniho Muzea V Praze (Acta Musei Nationalis Pragae), 12 (1967), 101-7; A. Matter, 'The Revelatio Esdrae in Latin and English tradition', Revue Bénédictine, 92 (1982), 376-92; D. Juste, 'Comput et divination chez Abbon de Fleury', in B. Obrist (ed.), Abbon de Fleury Philosophie, Science et Comput autour de l'an mil (Paris: Centres d'histoire des sciences et des philosophies arabes et médiévales, 2004); F. Fery-Hue, 'Revelatio Esdrae ou Prophéties d'Ezéchiel. Éléments nouveaux pour le corpus latin et français des prophéties d'après le jour de Noël', in M.C. Timelli and C. Galderisi (eds), Pour acquérir honneur et pris: mélanges de moyen français offerts à Giuseppe di Stefano (Montréal: Éditions Ceres, 2004), pp. 237-51; Sándor Chardonnens, Anglo-Saxon Prognostics, 900-1100: Study and Texts (Leiden: Brill, 2007), pp. 491-500; M. Cesario, 'Weather Prognostics in Anglo-Saxon England', English Studies, 93 (2012), 391-426.

${ }^{8}$ P. E. Dutton, 'Observations on early medieval weather in general, bloody rain in particular', in J. R. Davis and M. McCormick (eds), The Long Morning of Medieval Europe (Aldershot: Ashgate, 2008), pp. 167-80 (p. 168).

${ }^{9}$ Fol. 1r, containing two notes: one on scholastic work and another on the planets, which was not part of the original manuscript was added at a later stage.

${ }^{10}$ H. Broszinski (ed.), Die Handschriften der Murhardschen Bibliothek der Stadt Kassel und Landesbibliothek. Manuscripta Medica (Wiesbaden: Otto Harrassowitz, 1976), pp. 29-34. I am indebted to Dr David Juste for bringing this manuscript to my attention.

${ }^{11}$ I have made no attempt to normalise orthography or punctuation, apart from ' $u$ ' and ' $v$ '. $\backslash /$ refer to scribal insertions, mainly above the line. Abbreviations have been expanded silently. I have followed the order of the items as they appear in the 
manuscript, which is available online at http://orka.bibliothek.uni-

kassel.de/viewer/image/1358159248782/219/.

${ }^{12}$ Red capitals are used to mark the beginning of a new prognostic text.

${ }^{13}$ For 'pugne'.

${ }^{14}$ For the same day Heildelberg, UB, MS 213, fols $143 \mathrm{v}-144 \mathrm{r}$ also predicts that turpiores homines moriuntur.

${ }^{15}$ For this night, most Latin versions read 'viri ingrati'.

16 This could be an error for 'confragrentur' (to be burnt, to be on fire).

${ }^{17}$ Liège, Bibliothèque de l'Université, MS 77(s. xi/xii), fol. 69v and Oxford, Bodl, MS Digby 88, fol. 40r (s. xv) read 'letabuntur serui dei'. Both texts are edited by M.

Cesario, 'The Shining of the sun in the twelve nights of Christmas', in S. McWilliams (ed.), Saints and Scholars: New Perspectives on Anglo-Saxon Literature and Culture in Honour of Hugh Magennis (Cambridge: D.S. Brewer, 2012), pp. 195-212 (pp. 209-12).

${ }^{18}$ Space has been left unfilled here.

19 'Turpiores' could also be translated as 'morally deformed'.

${ }^{20}$ If the intended reading was 'confragrentur', then this prophecy should be translated:

'On the ninth night, timber will be on fire'.

${ }^{21}$ The existence of several versions, in different languages, together with a remarkable degree of variation, makes the textual tradition of such texts an extremely complex one. It is not the aim of this study to investigate each individual prognostication within the meteorological collection, and its relationship to other continental equivalents, in an attempt to establish source and origin. Instead I shall confine myself to addressing the main atmospheric, terrestrial and human concerns 
reflected in this ensemble of texts and the relationship between the weather material and the other items within the manuscript.

${ }^{22}$ The earliest Latin exemplar appears in the late eighth-century Voss. Lat. MS Q. 69, fol. 37v. For an edition of the text, see R. Bremmer, 'Leiden, Vossianus Lat. Q. 69 (part 2): schoolbook or proto-encyclopaedic miscellany?' in Rolf H. Bremmer and Kees Dekker (eds), Practice in Learning: The Transfer of Encyclopaedic Knowledge in the Early Middle Ages, pp. 19-53. See also Chardonnens, Anglo-Saxon Prognostics, pp. 491-2.

${ }^{23}$ Other attributions include: Ezechiel, Esdra and Joseph, Dionysius and Zephaniah. ${ }^{24}$ Florence, Biblioteca Riccardiana, Ricc. MS 1258, fols 88v-89v (Italy, s. xv), for example, mentions doglie di fianchi (stomach ache), sinchura di pecto (heart disease) and doglie di capo (headache), and Munich, BS, clm MS 10268, fol. 110rv reports that multe infirmitates erunt causa flatus (breathing will be the cause of many diseases).

${ }^{25}$ This is reinforced by the numerous finds of leather shoes from German coastal towns. For archaeological evidence, see G. P. Fehring, The Archaeology of Medieval Germany, trans. R. Samson (London: Routledge, 1991). See also J. Wubs-Mrozewicz, 'Shoes and shoemakers in late medieval Bergen and Stockholm', Collegium Medievale (2005), 1-29.

${ }^{26}$ Both texts are edited by R. M. Liuzza in 'What the thunder said: Anglo-Saxon brontologies and the problem of sources', RES, 55 (2004), 1-23. See also D. Juste and H. Chiu, 'The De tonitruis libellus attributed to Bede: an early medieval treatise on divination by thunder translated from Irish', Traditio, 68 (2013), 97-124.

${ }^{27}$ The prediction for the eighth day in another version of the sun prognostication in Cambridge, CCC MS 391, p. 713 reads that Gif by viii dage sunne scineð beorhte 
ponne bið cwicseolfer on angel kynne yð geate (if the sun brightly shines on the eighth day, then quicksilver will be easy to obtain among the English).

${ }^{28}$ Juste and Chiu, 'The De tonitruis libellus attributed to Bede', p. 6.

${ }^{29}$ For a study of wind prognostication, see M. Cesario, 'An English source for a Latin text? Wind prognostication in Oxford, Bodleian, Hatton 115 and Ashmole 345', Studies in Philology, 112 (2015), 213-33.

${ }^{30}$ Other versions of wind prognostication include: Oxford, Bodl., MS Digby 86, fol. 32r (s. xiii) Latin; Worcester, Cathedral Library, MS Q. 61, fol. 45r (s. xiii) Old French; Oxford, Bodl, MS Rawlinson C. 814, fol. 74r (s. xiv) Latin; Cambridge, Trinity College, MS R.7.23, fol. 261 (s. xiv) Latin; Paris, BN, n.a.l., MS 873, fol. 200r (s. xii) Latin; Oxford, Bodl, MS Ashmole 345, fol. 69r (s. xiv/xv) Latin; Columbia University Rare Book and Manuscript Library, MS Plimpton 260, fol. 32 (s. xv) Middle English; London, BL, MS Egerton 1995, fol. 60v (s. xv) Latin; Aberdeen, University Library, MS 123, fol. 154v (s. xv) Latin; London, BL, MS Sloane 282, fol. 86r (s. xv) Latin; London, BL, MS Sloane 2584, fol. 35v (s. xv); Latin London, BL, MS Additional 27582, fol. 266r (1523) and Heidelberg, UB, cpg, MS 226, fol. 51r (s. Xv) German (I owe this last reference to Sàndor Chardonnens).

${ }^{31}$ The prediction for the twelfth night is missing in Liège 77.

${ }^{32}$ Other versions of the sunshine prognostication include: Paris, BN, n.a.l., MS 873, fol. 200r (s. xii), Latin; Oxford, Bodl, MS Hatton 115, fols 149v-150r (s. xii), Old English; London, BL, MS Harley 2558, fol. 193v (s. xiv), Latin; Longleat House, MS 174, fol. 82 (s. xv), English; Oxford, Bodl, MS Digby 88, fol. 40r (s. xv) Latin. I am grateful to Sàndor Chardonnens and David Juste for bringing to my attention manuscripts I may have otherwise not found. 
${ }^{33}$ A bizarre prophecy concerning ants and camels appears in the Old English versions: MS Hatton 115, fols 149v-150r and CCCC MS 391, p. 713. See M. Cesario, 'Ant-lore in Anglo-Saxon England', Anglo-Saxon England, 40 (2011), 73-91.

${ }^{34}$ For a learned study on thunder divination, see Juste and Chiu, 'The De tonitruis libellus attributed to Bede'.

${ }^{35}$ A modern prognostic based on the cardinal points from which the wind blows is mentioned by M. Förster, 'Beiträge zur mittelalterlichen Volkskunde VI', Archiv, 128 (1912), 55-71 (64).

${ }^{36}$ Gerard M. Browne, Michigan Coptic Texts (Barcelona: Papyrologia Castroctaviana, 1979), p. 55.

${ }^{37}$ A. Leo Oppenheim, Ancient Mesopotamia: Portrait of a Dead Civilization (Chicago: University of Chicago Press, 1964), p. 211.

${ }^{38}$ Sunday was also believed to be a lucky day for babies born on that day.

${ }^{39}$ Three Mondays during the year were thought to be unlucky: the first Monday in April, the second in August, and the last in December. Ancient astronomers considered Tuesday bad because of its association with Mars; those born under Mars were likely to be choleric, warlike and contentious. Wednesday or die mercurii was the day on which Judas and the chief priests planned the betrayal of Christ (Mark 10:1). Thursday was linked to Jupiter, a good planet which is naturally moist and warm. Because it ruled the blood, people born under Jupiter were happy and generous. Friday was associated with Venus, a good planet because of its proximity to the sun; people born under Venus were both generous and happy. Finally, people born under the influence of Saturn were melancholic, taciturn and low-spirited because of the preponderance of water and earth, heavy elements, in their constitution.

${ }^{40}$ Hunt, Writing the Future, p. 13. 
41 It is unclear whether nominando simply refers to the naming of each hollow to its corresponding month, or whether the names of the months ought to be spoken in order for the prescribed actions to be validated.

${ }^{42}$ I am indebted to Vladimir Kuznetsov (Professor of Chemistry, University of Oxford) for his assistance on this matter. See http://dwb4.unl.edu/Chem/CHEM869B/CHEM869BLinks/www.chem.ualberta.ca/7E plambeck/che/p101/p01013a.htm.

${ }^{43} \mathrm{http}: / /$ cool.conservation-us.org/jaic/articles/jaic44-03-002_2.html;

http://www.omega.com/temperature/z/pdf/z103.pdf, and http://www.levity.com/alchemy/reid2-8.html. ${ }^{44}$ See http://lubbockonline.com/filed-online/2014-12-31/peffley-predict-2015rainfall-traditional-onion-calendar\#.VYMJ_c5N3zK; https://library.ndsu.edu/grhc/articles/newspapers/news/onion.html. ${ }^{45}$ Interestingly another fifteenth-century manuscript from Germany, Munich, BS, clm, MS 10268, fol. 110rv, for die martis predicts salis coagulatione.

${ }^{46}$ See R. Steele, 'Practical chemistry in the twelfth century Rasis de aluminibus et salibus', Isis, 12 (1929), 10-46 and J. Raske (ed. and trans.) Das Buch der Alaune und Salze. (The Book of Alums and Salts). A Source of Late Latin Alchemy (Berlin: Chemie, 1935).

${ }^{47}$ I follow Anke Timmermann's definition of alchemy as 'mostly relating to experiments and the transformation of matter'. See A. Timmermann (ed.), Verse and Transmutation: A Corpus of Middle English Alchemical Poetry (Critical Editions and Studies) (Leiden: Brill, 2013), p. 17.

${ }^{48}$ Robert B. Burke (trans.) The Opus Majus of Roger Bacon (2 vols. New York: Russell \& Russell, 1962), vol. II, part six: 'Experimental Science', p. 585. 
${ }^{49}$ In this paper I shall only consider, for comparative purposes, those collections in which the revelatio, wind, sun and thunder prognostications are part of the same section, and exclude consideration of those manuscripts which contain only one or two meteorological treatises. For instance, the appearance of the Christmas Day prognostication in association with the wind (generally either preceding or following it on the same folio) suggests that these two kinds of prognostication were probably circulating together, perhaps as part of the same booklet, since they are placed within the same period; Christmas Day is the first of the twelve nights of this period. ${ }^{50}$ MS 77 is a composite volume made of two parts, one dating from the eleventhtwelfth centuries, the other from the fourteenth. These two sections were part of two separate volumes before they were bound in together in the seventeenth century. The earlier book, which was copied on parchment, contains fols. 1-75 and Isabelle Draelants dates the handwriting of this section from the end of the eleventh century. See I. Draelants, Astrologie et Divination dans le MS 77 Bibl. Univ. Liège, fols $62 r-$ $70 v$ (Namur: $3^{\mathrm{e}}$ Congrès de 1'Association des cercles Francophones d'Histoire et d'Archéologie de Belgique, 1990), pp. 319-35 and M. Fiess and M. Grandjean, Bibliothèque de l'Université de Liège. Catalogue des manuscrits (Liège: Université de Liège, 1875), pp. 264-7, n. 470.

${ }^{51}$ See Juste and Chiu, 'The De tonitruis libellus' and Draelants, Astrologie et Divination.

${ }^{52}$ For a description of Hatton 115, see N. R. Ker (ed.), Catalogue of Manuscripts Containing Anglo-Saxon (1957, reissued with Supplement; Oxford: Clarendon Press, 1990), no. 32, p. 402; E. Treharne, 'The dates and origins of three twelfth-century manuscripts', in P. Pulsiano and E. Treharne (eds), Anglo-Saxon Manuscripts and their Heritage: Tenth to Twelfth Centuries (Aldershot: Ashgate, 1998), pp. 227-52 
and Chardonnens, Anglo-Saxon Prognostics.

${ }^{53}$ L. Thorndike, 'Eclipses in the fourteenth and fifteenth centuries,' Isis, 48 (1957), $51-7$.

${ }^{54}$ See R. Steele and A. S. Fulton (eds), Secretum secretorum, Opera hactenus inedita Roberti Baconi, 5 (Oxford: Clarendon Press, 1928).

${ }^{55}$ A brief description of the manuscript is available at https://www.bl.uk/catalogues/illuminatedmanuscripts/record.asp?MSID=1235\&CollI $\mathrm{D}=9 \& \mathrm{NStar}=282$.

${ }^{56}$ London, BL, MS Cotton Tiberius A.iii, fol. 36rv and fols 41v-42r (s. xi, Canterbury) and London, BL, MS Cotton Titus D.xxvi-xxvii, fols 10v-11v and fol. 25rv (s. xi, Winchester) also contain two versions of the revelatio.

${ }^{57}$ There had always been difficulty in determining when New Year's Day fell, since the beginning of the year was calculated differently by different civilizations in different periods: 1 January, Christmas Day, the first day of Advent and 25 March were all common dates. See R. L. Poole, Studies in Chronology and History (Oxford: Clarendon Press, 1934). Weather prognostics began to be attached to Christmas Day in the eleventh century in Latin, and they occur somewhat later in many medieval manuscripts, especially from England and France.

${ }^{58} \mathrm{~A}$ closer inspection of $\mathbf{K}$ is needed in order to determine whether the manuscript is made of separate quires which were bound together at a later stage.

${ }^{59}$ According to Linne R. Mooney, scientific and utilitarian texts 'range from learned treatises on astronomy, medicine, arithmetic, geometry, agriculture, and husbandry to treatises on the medieval conception of prognostication, magic, alchemy, geomancy, astrology and physiognomy' (L. R. Mooney, 'Manuscript evidence for the use of medieval English scientific and utilitarian texts', in R. F. Green and L. R. Mooney 
(eds), Interstices. Studies in Middle English and Anglo-Latin Texts in Honour of A. G. Rigg (Toronto: Toronto University Press, 2004)), p. 184.

${ }^{60}$ R. M. Liuzza (ed. and trans.), Anglo-Saxon Prognostics: An Edition and Translations of Texts from London, British Library, MS Cotton Tiberius A. iii (Woodbridge: Boydell \& Brewer, 2011), p. 60.

${ }^{61}$ Hunt, Writing the Future, p. 11.

${ }^{62}$ By contrast, folding medical almanacs containing prognostications like Oxford, Bodl, MS Rawlinson D. 393, which were meant to be carried around hanging from the physician's belt, most likely served a utilitarian purpose. See Mooney, 'Manuscript evidence', p. 189.

${ }^{63}$ Chardonnens, Anglo-Saxon Prognostics, p. 141.

${ }^{64}$ Ibid.

${ }^{65}$ I am grateful to Dr Christina Lee and Dr Freya Harrison for their suggestions. 